\title{
Germination and Resistance Defects in Spores of a Bacillus subtilis Mutant Lacking a Coat Polypeptide
}

\author{
By H. F. JENKINSON \\ Microbiology Unit, Department of Biochemistry, University of Oxford, \\ Oxford $O X 13 Q U, U . K$.
}

(Received 13 March 1981)

Spores produced by a mutant of Bacillus subtilis germinate slowly and are sensitive to lysozyme. The spore coat of the mutant appears to lack a single polypeptide (mol. wt 36000 ) which normally is deposited in the outer layers of the spore during stage $\mathrm{V}$ of sporulation. The mutation maps between leuA and $\arg A$ on the $B$. subtilis chromosome and is genotypically and phenotypically distinct from another mutation ger-36 which maps in the same region: consequently it has been assigned a new locus spoVIA. The phenotype of the mutant confirms a previous suggestion that lysozyme resistance is conferred by the outermost layers of the spore coat.

\section{INTRODUCTION}

The spore coat in Bacillus subtilis contains about 12 polypeptides (Pandey \& Aronson, 1979; Jenkinson et al., 1981). These are synthesized at different times during sporulation and are incorporated into the spore structure during stages V and VI (Jenkinson et al., 1981). One component of the $B$. subtilis spore coat, a polypeptide with a molecular weight of approximately $36000(36 \mathrm{~K})$, begins to be formed particularly late in sporulation (after $t_{6}$ ) and is deposited in the outermost layers of the maturing spore. Its appearance is inhibited by the late addition of chloramphenicol during sporulation, and spores produced in the presence of chloramphenicol are sensitive to lysozyme, though heat-resistant (Jenkinson et al., 1980). This suggested a direct role for the $36 \mathrm{~K}$ polypeptide in conferring lysozyme resistance upon the spores.

During sporulation not only the resistance properties but also the germination properties of the spores develop in parallel with the laying down of the coat proteins (Dion \& Mandelstam, 1980; Jenkinson et al., 1980). If both germination and resistance properties are determined by the proteins of the coat, it should be possible to isolate mutants which are affected both in coat structure and in these properties. In this paper a mutant of $B$. subtilis is described which produces spores that have a specific defect in the outer coat layers. The spores are fully heat-resistant but have a delayed response to germinants and are lysozyme-sensitive. The coat of the mutant (strain 513 ) lacks the $36 \mathrm{~K}$ polypeptide; consequently some proteins in the spore outer layers which are normally covered, presumably by the $36 \mathrm{~K}$ polypeptide, are exposed on the outer surface of the spores. The mutation has been located between leuA and $\arg A$ on the $B$. subtilis map, appears to be separate from ger-36 which maps close by (Moir et al., 1979), and defines a new sporulation locus spoVIA.

\section{METHODS}

Bacteria. Bacillus subtilis 168 trpC2 which requires indole or tryptophan and sporulates normally was used as the standard strain and is referred to as the wild-type. The other auxotrophic strains used are shown in Table 1; these are all $\mathrm{Spo}^{+}$. 
Table 1. Strains of Bacillus subtilis used

\begin{tabular}{cl}
$\begin{array}{c}\text { Strain } \\
\text { designation }\end{array}$ & \multicolumn{1}{c}{ Genotype } \\
MB21 & leu-8 metC3 tal-1 \\
MB26 & leu-8 phe-12 rif-2 tal-1 \\
MB68 & phe-12 lys-1 rif-2 tal-1 \\
BD40 & phe-12 argA3 ery \\
BD54 & leu-8 metB5 ile-1 \\
BD163 & hisA1 argC4 \\
87.2 & leu-8 tal-1 spoOJ \\
E36 & leu-2 ger-36
\end{tabular}

$\quad$ Source
This laboratory
This laboratory
This laboratory
D. Dubnau
D. Dubnau
D. Dubnau
Hranueli et al. (1974)
Moir et al. (1979)

Growth and sporulation. Sporulation was induced by transferring exponentially growing cells at $37^{\circ} \mathrm{C}$ to resuspension medium (Sterlini \& Mandelstam, 1969). Times after resuspension (h) are denoted $t_{1}, t_{2}$, etc.; at $t_{8}, 80$ to $90 \%$ of the cells contained refractile spores. Spore incidence was determined by phase-contrast microscopy.

Measurement of resistances to organic solvents, heat and lysozyme. Resistances to toluene and octan-1-ol $(0.02$ vol. $)$, heat $\left(80^{\circ} \mathrm{C}, 15 \mathrm{~min}\right)$ and lysozyme $(250 \mu \mathrm{g} \mathrm{ml}$ described (Jenkinson et al., 1980).

Measurement of resistances to acetone, phenol and trichloroacetic acid. A portion of spore suspension $(0.5 \mathrm{ml})$ containing about $10^{8}$ spores was added to $4.5 \mathrm{ml}$ of acetone $\left(20^{\circ} \mathrm{C}\right)$, phenol $\left(5 \%, \mathrm{w} / \mathrm{v}, 4^{\circ} \mathrm{C}\right)$ or trichloroacetic acid $\left(5 \%, w / v, 4^{\circ} \mathrm{C}\right)$, left for $15 \mathrm{~min}$ with occasional vortex mixing, and then suitable dilutions were plated on nutrient agar (Oxoid).

Assays for sporulation marker events. Extracellular serine protease was measured as described by Dancer \& Mandelstam (1975). Alkaline phosphatase was measured by the method of Glenn \& Mandelstam (1971). Manganese-dependent deoxyribonuclease was assayed by the method of Akrigg (1978) and glucose dehydrogenase was determined by the method of Sadoff (1966). Dipicolinic acid was determined by the method of Janssen et al. (1958).

Isolation of lysozyme-sensitive mutants. The initial procedure used was to select germination mutants as described by Trowsdale \& Smith (1975). An exponentially growing culture of the wild-type in 50 ml hydrolysed casein medium (Sterlini \& Mandelstam, 1969) was centrifuged and the cells were suspended to a density of about $2 \times 10^{9}$ cells $\mathrm{ml}^{-1}$ in glutamate minimal (resuspension) medium and shaken at $37^{\circ} \mathrm{C}$. $N$-Methyl- $N^{\prime}$ nitro- $N$-nitrosoguanidine was added (final concn $100 \mu \mathrm{g} \mathrm{ml}^{-1}$ ) and samples $(2 \mathrm{ml}$ ) were removed after 15,30 and $45 \mathrm{~min}$. The bacteria in each sample were washed, resuspended to $5 \mathrm{ml}$, and $1 \mathrm{ml}$ portions were inoculated into $10 \mathrm{ml}$ portions of hydrolysed casein medium. The flasks were shaken overnight at $37^{\circ} \mathrm{C}$, and dilutions were plated on lactate/glutamate minimal agar (Piggot, 1973) to give about 100 colonies per plate. The spores were collected from each plate after $4 \mathrm{~d}$ at $37^{\circ} \mathrm{C}$, suspended in Difco Penassay broth $(20 \mathrm{ml})$ to a density of about $4 \times 10^{8}$ spores $\mathrm{ml}^{-1}$ and heated at $80^{\circ} \mathrm{C}$ for $10 \mathrm{~min}$. The spores were allowed to germinate at $42^{\circ} \mathrm{C}$ for $2 \mathrm{~h}$ and then each suspension was heated again at $80^{\circ} \mathrm{C}$ for $30 \mathrm{~min}$ to kill spores that had germinated normally. The suspensions were left shaking at $37^{\circ} \mathrm{C}$ for $16 \mathrm{~h}$, then heated $\left(80^{\circ} \mathrm{C}, 15 \mathrm{~min}\right)$ to kill vegetative cells, and suitable dilutions were plated on Difco tryptose blood agar base containing Oxoid nutrient broth $\left(0.8 \%\right.$, w/v). After $24 \mathrm{~h}$ at $37^{\circ} \mathrm{C}$ about 100 colonies which were more translucent than the others, and which appeared at a frequency of about $5 \%$, were picked from the plates and streaked on lactate/glutamate minimal agar. After $4 \mathrm{~d}$ at $37^{\circ} \mathrm{C}$ to allow sporulation to occur on the plates, a single colony from each isolate was suspended in $2 \mathrm{ml}$ resuspension medium. The suspensions were heated $\left(80^{\circ} \mathrm{C}, 30 \mathrm{~min}\right)$, cooled and samples were removed for determination of the numbers of heat-resistant spores. To each suspension was then added $0.2 \mathrm{ml}$ of a lysozyme solution $\left(2 \mathrm{mg} \mathrm{ml}^{-1}\right)$, and after incubation for $1 \mathrm{~h}$ at $37^{\circ} \mathrm{C}$ the number of survivors in each was determined by plating samples on nutrient agar. In this way, five clones were picked on the basis of their forming heat-resistant and lysozyme-sensitive spores. All these strains grew normally at $37^{\circ} \mathrm{C}$ in hydrolysed casein medium and in glucose/glutamate minimal medium (Coote, 1972a).

Genetic mapping. Genetic mapping was done by transduction with phage PBS1 (Takahashi, 1963) using lysates, prepared as described by Karamata \& Gross (1970) from the lysozyme-sensitive strain, as donor in crosses with a set of recipient strains (see Table 1). For the determination of recombination indices (Coote, $1972 b$ ), DNA from the donor strains was prepared by the method of Marmur (1961) from cells grown in Penassay broth and used at a concentration of about $5 \mu \mathrm{g} \mathrm{m} l^{-1}$ to transform competent cells (Ayad \& Barker, 1969). Transductants or transformants were selected on lactate/glutamate minimal plates with appropriate supplements. Plates were incubated for $4 \mathrm{~d}$ at $37^{\circ} \mathrm{C}$ to allow the development of the brown pigment characteristically associated with sporulation. Colonies that were brown and opaque were recorded as $\mathrm{Spo}^{+}$(sporogenous) and those which were less brown and more transparent were recorded as $\mathrm{Spo}^{-} / \mathrm{Ger}^{-}$(sporulation/germination defective). However, distinguishing between $\mathrm{Spo}^{+}$and $\mathrm{Spo}^{-}$in this way alone was unreliable because the auxotrophic strains used for 
mapping varied sufficiently in their degree of pigment formation and colony opacity to interfere with the scoring of colonies. Therefore, single-colony isolates were obtained from the transductant colonies and scored for the cotransfer of the germination defect by the tetrazolium overlay method (Lafferty \& Moir, 1977). Although this method of scoring was more reliable, for some crosses it was also unsatisfactory because the recipient strains themselves varied in their tetrazolium reaction. Accordingly, for each cross where linkage was suspected, at least 20 single-colony isolates of the transductants were further tested by (a) suspending a sporulating colony in resuspension medium and measuring the number of survivors after treatment with heat $\left(80^{\circ} \mathrm{C}, 15 \mathrm{~min}\right)$ and then lysozyme and (b) growing and resuspending colonies by the Sterlini \& Mandelstam (1969) method and determining heat and lysozyme resistances at $t_{10}$. Lysozyme sensitivity and germination deficiency were $100 \%$ cotransducible.

Genetic linkage is recorded as the percentage cotransduction of the mutation with the marker tested. The relatively low numbers of transductants tested were due to these difficulties in scoring (see above).

Preparation of spores. Spores from cultures at $t_{20}$ were harvested by centrifugation $\left(8000 \mathrm{~g}, 20 \mathrm{~min}, 4^{\circ} \mathrm{C}\right)$, washed twice with $1 \mathrm{M}-\mathrm{KCl}$, once with deionized water and then pelleted by centrifugation through $40 \%(\mathrm{w} / \mathrm{v})$ Urografin. After three further washings with deionized water containing $0.01 \%(\mathrm{v} / \mathrm{v})$ Tween 80 , the final preparations contained about $98 \%$ phase-bright spores. Spores from cultures at $t_{9}$ or $t_{10}$ were prepared by passing the sporangia through a French pressure cell and then washing the spores as previously described (Jenkinson $e t$ al., 1981).

Germination characteristics of spores. Cleaned spores (see above) from cultures at $t_{20}$ were heat-activated $\left(75^{\circ} \mathrm{C}, 15 \mathrm{~min}\right.$ ) and suspended to a density of about $5 \times 10^{7}$ spores $\mathrm{ml}^{-1}$ in appropriate germination medium at $30^{\circ} \mathrm{C}$. The course of germination was followed by measuring (a) the loss in absorbance of the suspension at 600 $\mathrm{nm}$, (b) the loss in the numbers of spores surviving treatment with toluene and (c) the approximate increase in the proportion of phase-dark to phase-bright spores.

Extraction of spore coat proteins. Cleaned and washed spores were suspended to a density of about $2 \times 10^{9}$ spores $\mathrm{ml}^{-1}$ in $10 \mathrm{ml}$ Tris/HCl buffer $(50 \mathrm{mM}, \mathrm{pH} 7.5)$ containing EDTA (10 mM) and phenylmethylsulphonyl fluoride (PMSF; $2 \mathrm{mM}$ ), mixed with $7 \mathrm{ml}$ glass beads, broken in a Braun cell homogenizer, and the insoluble fraction thus generated was extensively washed (Jenkinson et al., 1981). The spore coat proteins were extracted with DS buffer [cyclohexylaminoethanesulphonic acid (CHES)/ $\mathrm{NaOH}(5 \mathrm{mM}, \mathrm{pH} 9.8$ ) containing sodium dodecyl sulphate (SDS; 2\%, w/v) and dithioerythritol (DTE; $50 \mathrm{~mm}$ )] at $70{ }^{\circ} \mathrm{C}$ for $30 \mathrm{~min}$. Protein solubilized was measured by the Lowry method. Extracts were centrifuged $(2000 \mathrm{~g}, 4 \mathrm{~min}$ ) before being subjected to SDS-PAGE (see below).

Radioactive labelling. Cell proteins of the sporangia were labelled and extracted as follows. A portion (0.5 ml) of sporulating culture was incubated with shaking with $\mathrm{L}-\left[\mathrm{U}-{ }^{14} \mathrm{C}\right]$ tyrosine $[0.3 \mu \mathrm{Ci}(11 \cdot 1 \mathrm{kBq}), 3 \mu \mathrm{g}]$ for $15 \mathrm{~min}$ at $37^{\circ} \mathrm{C}$. The cells were harvested by centrifugation (Beckman Microfuge, $30 \mathrm{~s}$ ), washed once with $\mathrm{NaCl}(1 \mathrm{M})$ and then resuspended at $40^{\circ} \mathrm{C}$ for $20 \mathrm{~min}$ in $0.02 \mathrm{ml}$ 'lysis buffer' [Tris/ $\mathrm{HCl}(50 \mathrm{mM}, \mathrm{pH} \mathrm{8.2)}$ containing EDTA ( $2 \mathrm{~mm}$ ), PMSF $\left(0.3 \mathrm{mg} \mathrm{ml}^{-1}\right)$, lysozyme $\left(2 \mathrm{mg} \mathrm{ml}^{-1}\right.$ ) and DNAase I (Worthington; $\left.100 \mu \mathrm{g} \mathrm{ml} \mathrm{m}^{-1}\right)$ ]. The suspension was then heated at $80^{\circ} \mathrm{C}$ for $15 \mathrm{~min}$ with $0.05 \mathrm{ml}$ 'cracking buffer' [CHES/ $\mathrm{NaOH}(5 \mathrm{mM}, \mathrm{pH} \mathrm{9.8)}$ containing SDS $(2 \%, w / v)$, DTE $(60 \mathrm{~mm})$, glycerol $(15 \%, v / v)$ and bromophenol blue $(0.005 \%, w / v)]$, centrifuged $(2000 \mathrm{~g}, 4 \mathrm{~min})$, and a portion of the supernatant was counted for radioactivity before subjecting the extract to SDS-PAGE.

Measurement of radioactivity. Aqueous samples $(0.01-0.5 \mathrm{ml})$ were treated with ethanol $(6 \mathrm{ml})$ and Omnifluor (New England Nuclear) in toluene $(0.5 \%, w / v ; 8 \mathrm{ml})$ and counted in a liquid scintillation counter (LKB Wallac 81000).

$S D S$-polyacrylamide gel electrophoresis (SDS-PAGE). Proteins were fractionated by electrophoresis on SDS-acrylamide slab gels ( $1.5 \mathrm{~mm}$ thick) prepared as described by Laemmli \& Favre (1973). The separating gel contained $14.5 \%(\mathrm{w} / \mathrm{v})$ acrylamide and $0.25 \%(\mathrm{w} / \mathrm{v}) N, N^{\prime}$-methylenebisacrylamide; the corresponding concentrations in the stacking gel were $5 \%$ and $0.38 \%$. Samples to be electrophoresed were made, when necessary, to $0.002 \%(\mathrm{w} / \mathrm{v})$ in bromophenol blue and $10 \%(\mathrm{v} / \mathrm{v})$ in glycerol and heated to $100{ }^{\circ} \mathrm{C}$ for $5 \mathrm{~min}$ before loading. Electrophoresis and staining were done as previously described (Jenkinson et al., 1981). Stained gels were scanned with a double-beam recording microdensitometer (Joyce, Loebl \& Co., Gateshead, U.K.). Molecular weights of proteins were estimated from their distances of migration by reference to a graph relating migration distances of six marker proteins to log molecular weight. The markers used were phosphorylase b (mol. wt 94000 ), bovine serum albumin (67000), ovalbumin (43000), carbonic anhydrase (30000), soybean trypsin inhibitor (20100) and $\alpha$-lactalbumin (14400) (Pharmacia). Protein bands labelled with ${ }^{14} \mathrm{C}$ were visualized by fluorography (Bonner \& Laskey, 1974; Laskey \& Mills, 1975).

Surface protein iodination. Cleaned spores $\left(3-5 \mathrm{mg}\right.$ dry wt) were surface-labelled with ${ }^{125} \mathrm{I} 10 \cdot 15 \mathrm{mCi}$ (5.55 MBq)] using lactoperoxidase (EC 1.11.1.7; Sigma) as previously described (Jenkinson et al., 1981). The spore coat proteins were fractionated by SDS-PAGE and the ${ }^{125} \mathrm{I}$ associated with each band was determined by counting $1 \mathrm{~mm}$ slices of the excised lane in a LKB Wallac 1270 Rackgamma counter. 
Chemicals. Acrylamide and $N, N^{\prime}$-methylenebisacrylamide were obtained from $\mathrm{BDH}, \mathrm{L}-\left[\mathrm{U}-{ }^{14} \mathrm{C}\right]$ tyrosine was purchased from Amersham, and iodine-125 was from New England Nuclear. All other chemicals were from Sigma unless otherwise stated.

\section{RESULTS}

Sporulation and resistance properties of strain 513. After mutagenesis and isolation of colonies in which the spores were sensitive to lysozyme (see Methods), five mutants were selected for further study. Spores formed by one of these (strain 513) appeared to be the most sensitive to lysozyme. This strain sporulated normally, producing amounts of extracellular serine protease, alkaline phosphatase, endonuclease, glucose dehydrogenase and dipicolinic acid similar to those of the wild-type strain, and the spores were released from the sporangia after 12 to $15 \mathrm{~h}$ incubation at $37^{\circ} \mathrm{C}$.

A spore suspension of the mutant harvested and cleaned at $t_{10}$ was tested for resistance to toluene, octan-1-ol, acetone, trichloroacetic acid, phenol, heat $\left(80^{\circ} \mathrm{C}, 15 \mathrm{~min}\right)$ and lysozyme. The spores resisted all these treatments except the last which gave about a fivefold reduction in viable count in $30 \mathrm{~min}$. In Tris $/ \mathrm{HCl}$ buffer $(50 \mathrm{mM}, \mathrm{pH} \mathrm{7.4)} \mathrm{containing} \mathrm{lysozyme}$ $\left(250 \mu \mathrm{g} \mathrm{ml}^{-1}\right), 90 \%$ or more of the spores of strain 513 lost viability in $2 \mathrm{~h}$ (Fig. 1); during this time there was no loss in viability of wild-type spores.

Germination properties. Since this strain was isolated by a procedure that was designed to select slow germinators (see Methods), it was expected that the spores would show some germination defect. The germination of strain 513 in L-alanine (10 mM) was severely delayed and, as measured by toluene resistance, only about $35 \%$ of the spores had germinated after

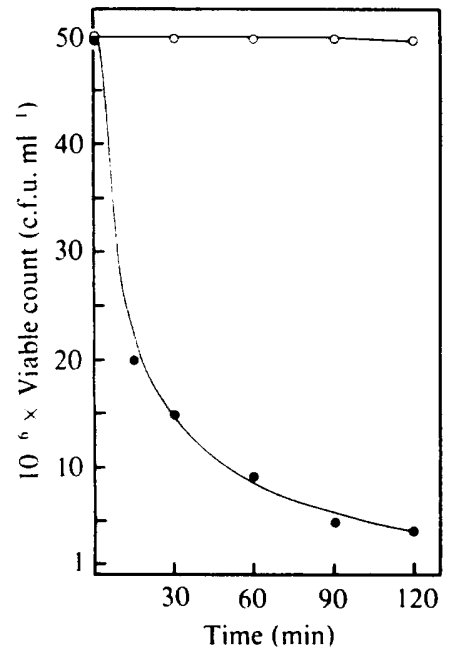

Fig. 1

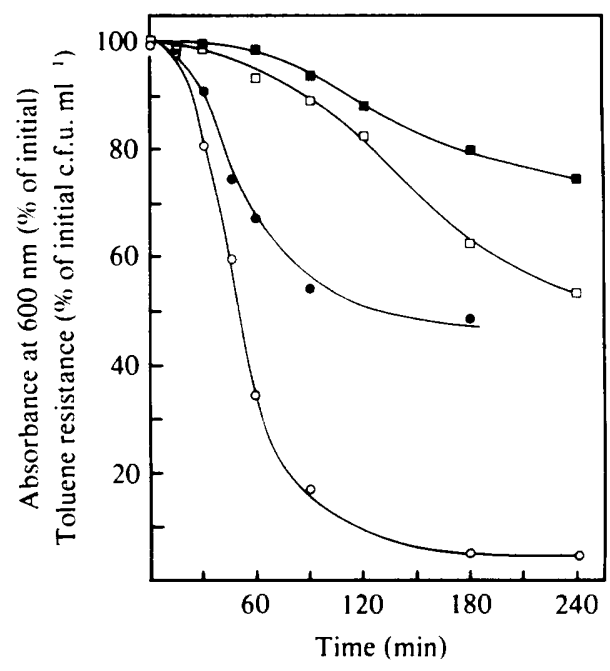

Fig. 2

Fig. 1. Effect of prolonged lysozyme treatment on viability of spores of strain $168(O)$ and strain 513 (O). Cleaned spores at $t_{10}$ were suspended to a density of $5 \times 10^{7}$ colony-forming units (c.f.u.) $\mathrm{ml}^{-1}$ in Tris $/ \mathrm{HCl}$ buffer $(50 \mathrm{~mm}, \mathrm{pH} 7.4)$ containing lysozyme $\left(250 \mu \mathrm{g} \mathrm{ml} \mathrm{m}^{-1}\right)$ at $37^{\circ} \mathrm{C}$ and samples were removed at intervals for the determination of viable count.

Fig. 2. Germination of spores of strain 168 and strain 513 . Cleaned spores from cultures at $t_{20}$ were heat-activated $\left(75^{\circ} \mathrm{C}, 15 \mathrm{~min}\right)$ and then suspended to a density of $5 \times 10^{7}$ c.f.u. $\mathrm{ml}^{-1}$ in Tris/ $\mathrm{HCl}$ buffer $(10 \mathrm{~mm}, \mathrm{pH} 8.2)$ containing $\mathrm{L}$-alanine $(10 \mathrm{~mm})$ at $30^{\circ} \mathrm{C}$. Samples were withdrawn at intervals and germination was determined by toluene resistance and absorbance (see Methods). Toluene resistance: $168(0): 513(\square)$. Absorbance: $168(0) ; 513(\square)$. 


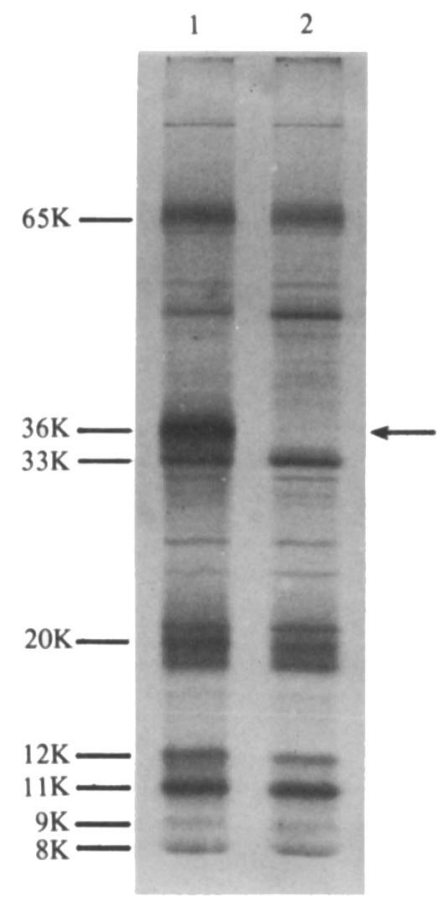

Fig. 3. SDS-PAGE patterns (stained with Coomassie blue) of proteins in spore coat fractions from $t_{9}$ spores of strain 168 (lane 1) and strain 513 (lane 2). The spore coat fractions were prepared and the proteins were solubilized as described in Methods. The coat protein bands are referred to by their apparent molecular weights. The same amount of protein $(40 \mu \mathrm{g})$ was applied to each lane. The arrow marks the region of the missing $36 \mathrm{~K}$ polypeptide.

$3 \mathrm{~h}$, compared with $95 \%$ in the wild-type (Fig. 2). Loss of toluene resistance was reflected by loss of absorbance in both strain 513 and strain 168 (Fig. 2) and in both strains the spores which germinated became phase-dark.

Germination of strain 513 spores was also delayed in Penassay broth (results not shown). Neither spores from strain 513 nor those from strain 168 germinated in a mixture of $\mathrm{KCl} /$ glucose/fructose (Dion \& Mandelstam, 1980).

Spore coat proteins. The altered lysozyme sensitivity and germination properties might have been due to an alteration in spore coat structure. Therefore, spores of the mutant strain were purified (see Methods) and broken, and the proteins of the spore coat fraction were solubilized with DS buffer and fractionated by SDS-PAGE. Coomassie blue staining showed that the spore coat of the mutant lacks a single polypeptide (Fig. 3) with a molecular weight of: about $36000(36 \mathrm{~K})$. The distribution and relative intensities of the other polypeptides in the coat extract from strain 513 were the same as in the wild-type.

Radioactive labelling of sporangia. Two explanations for the missing $36 \mathrm{~K}$ polypeptide were considered: (a) the protein was not synthesized, or (b) it was made but not incorporated into the coat. In an attempt to distinguish between these two possibilities, sporulating cells were pulse-labelled at intervals during sporulation with $\left[{ }^{14} \mathrm{C}\right]$ tyrosine (see Methods). The sporangia were then lysed and extracted, and the proteins were separated by SDS-PAGE. If the $36 \mathrm{~K}$ polypeptide, which is known to be made late in sporulation (Jenkinson et al., 1981), was formed but not incorporated into the spore structure, then it should be detectable in extracts from whole cells labelled after $t_{6}$, but not in those labelled earlier. The pattern of 

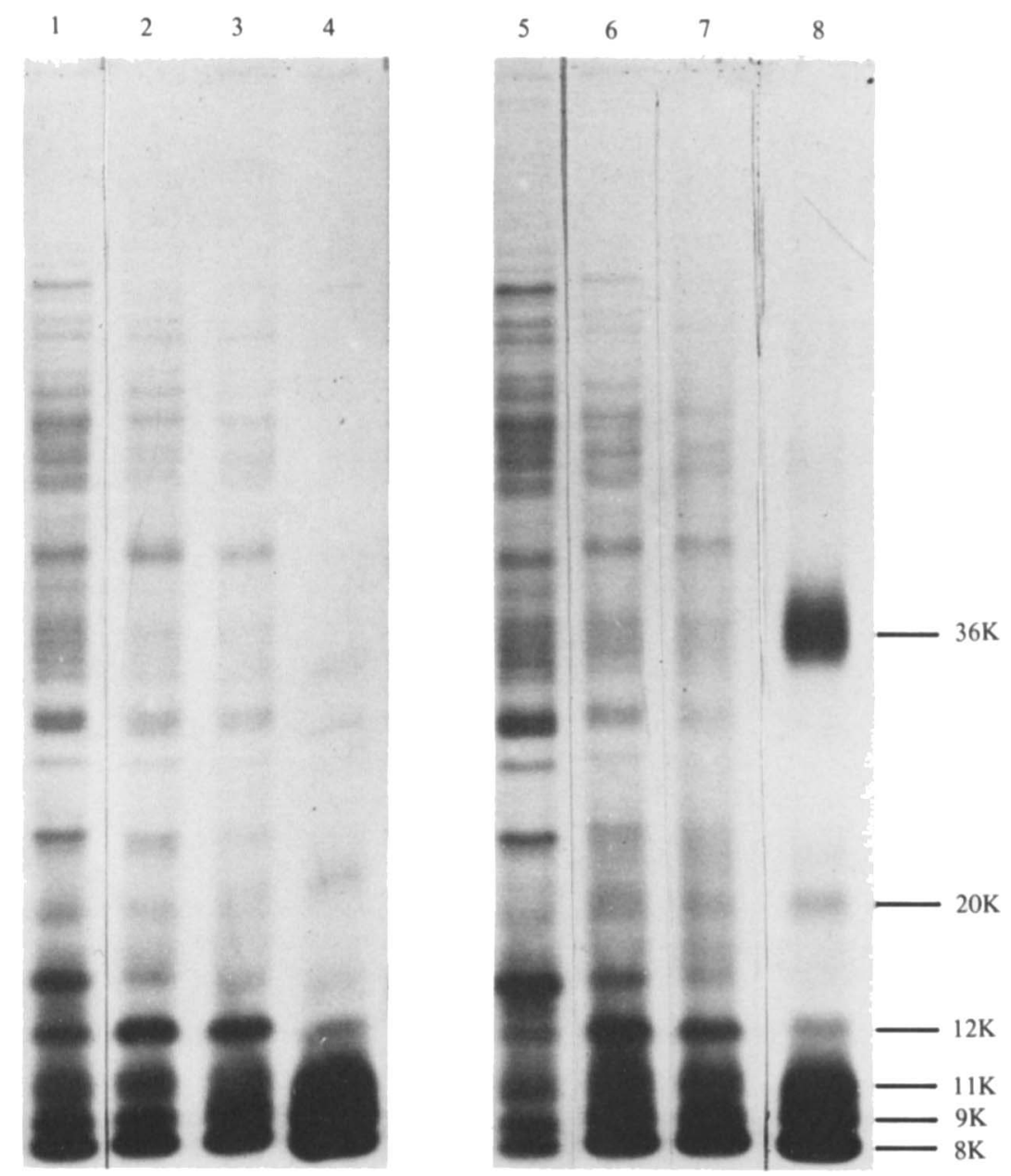

Fig. 4. SDS-PAGE patterns (revealed by fluorography) of proteins extracted from sporulating cells at various times during sporulation after labelling with $\left[{ }^{14} \mathrm{C}\right]$ tyrosine for $15 \mathrm{~min}$ (see Methods). Lanes $1-4$ : sporulating cells of strain 513 labelled at $t_{4}, t_{5}, t_{6}$ and $t_{7}$, respectively. Lanes 5-8: sporulating cells of strain 168 labelled at $t_{4}, t_{5}, t_{6}$ and $t_{7}$, respectively. The spore coat proteins are indicated (see Fig. 3).

labelled proteins in strain 513 at $t_{4}, t_{5}$ and $t_{6}$ was similar to that of strain 168 at the same times (Fig. 4). Several of the coat polypeptides which contain a high amount of tyrosine and which began to appear at $t_{4}$ could be clearly identified in the whole cell extracts (Fig. 4). At $t_{7}$, however, the $36 \mathrm{~K}$ polypeptide was apparent in extracts from the cells of strain 168 but not in those from strain 513 (Fig. 4). Thus the mutant appears not to make this polypeptide.

In vitro labelling of surface proteins with ${ }^{125} \mathrm{I}$. The $36 \mathrm{~K}, 12 \mathrm{~K}, 9 \mathrm{~K}$ and $8 \mathrm{~K}$ polypeptides have been identified by surface labelling with ${ }^{125} \mathrm{I}$ as being the major surface proteins in mature spores (Jenkinson et al., 1981). The same technique was used to determine which proteins were exposed on the surface of spores of strain 513. The pattern in Fig. 5 shows labelling of the following polypeptides: $65 \mathrm{~K}, 33 \mathrm{~K}, 30 \mathrm{~K}, 24 \mathrm{~K}, 20 \mathrm{~K}, 19 \mathrm{~K}, 15 \mathrm{~K}, 12 \mathrm{~K}, 9 \mathrm{~K}$ and $8 \mathrm{~K}$. This is very different to the pattern of labelling in the wild-type where the $30 \mathrm{~K}$ and $15 \mathrm{~K}$ polypeptides are completely covered by the overlying proteins (see Fig. 5 inset), and three others $(24 \mathrm{~K}, 20 \mathrm{~K}$ and $19 \mathrm{~K})$ are largely covered. 


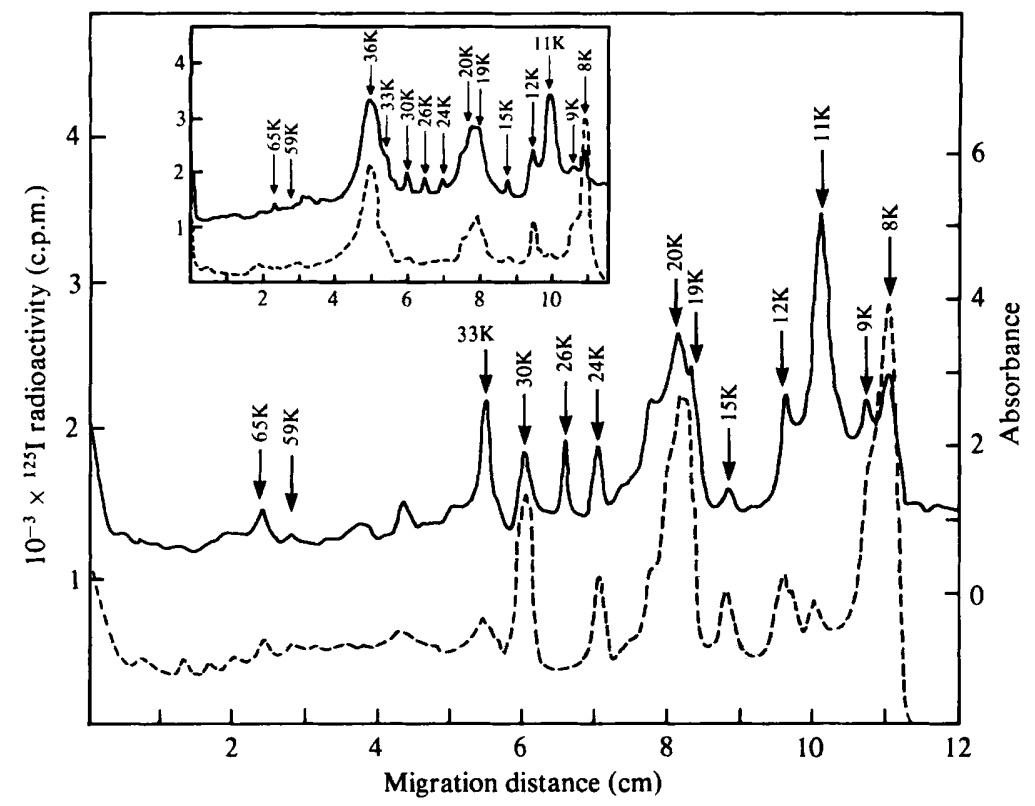

Fig. 5. Proteins exposed on the surface of $t_{9}$ spores of strain 513. The spores were surface-labelled with ${ }^{125}$ I using lactoperoxidase, washed and broken with glass beads, and the proteins of the spore coat fraction were separated by SDS-PAGE. The gels were stained with Coomassie blue, scanned with a densitometer and then sliced into $1 \mathrm{~mm}$ sections which were counted for radioactivity in a gamma counter. - - Densitometer scan (absorbance); - - - ${ }^{125} \mathrm{I}$ radioactivity. The inset shows the corresponding scan for spores of strain 168 surface-labelled at $t_{9}$ (see Jenkinson et al., 1981).

Construction of an isogenic strain. It was important to try to rule out the possibility that strain 513 contained multiple genetic defects. This was done by transferring the mutation to strain MB21 leu-8 metC3 by transformation with a saturating amount $\left(5 \mu \mathrm{g} \mathrm{ml}^{-1}\right)$ of purified DNA from strain 513. Seven out of $100 \mathrm{Met}^{+}$transformants tested were $\mathrm{Ger}^{-}$by the tetrazolium overlay method, and showed the heat-resistant, lysozyme-sensitive phenotype. This is approximately the number that would be expected from transformation by congression. Three of these transformants were further characterized: each carried the germination defect of the original mutant (see Fig. 2) and the coat polypeptide profile of each was identical to that shown for strain 513 in Fig. 3. Thus, the phenotype of strain 513 is unlikely to have been caused by more than one distinct mutational event. Reversion tests may help to establish that the altered spore properties are the result of a point mutation.

Genetic mapping. The mutation was not cotransduced with $\arg C$, metC, ilvA, metB, lys or his $A$. It was $45 \%(34 / 75)$ cotransducible with $\arg A$ (map position 260$), 67 \%(56 / 84)$ with leuA (map position 250$)$ and $23 \%(23 / 100)$ with pheA (map position 245 ). The gene order suggested from three-point transduction crosses was pheA-leuA-spo-argA (Table 2).

The ger-36 mutation also maps in this region (Moir et al., 1979) but is highly cotransducible with leuA (92\%). The phenotype of strain E36 which carries this mutation is similar to that of strain 513 in that it forms spores that are germination-defective and lysozyme-sensitive. However, the two strains differ in two respects: (a) electron micrographs of thin sections of strain E36 spores show the coat to be incomplete (Moir et al., 1979) but in strain 513 there is no obvious abnormality (results not shown); (b) the SDS-PAGE profile of the spore coat proteins of strain E36 is different from that of strains 513 and 168 (results not shown). These differences indicate that the mutation in strain E36 was not the same as that in strain 513 and that the mutations were unlikely to be in the same gene. To check this, the 
Table 2. Three-factor transduction crosses with strains $M B 26$ and BD40 as recipients

The donor was strain 513 (trpC2 spo-513).

\begin{tabular}{|c|c|c|c|}
\hline Recipient & Selection & $\begin{array}{c}\text { Recombinant } \\
\text { class }\end{array}$ & $\begin{array}{l}\text { No. in } \\
\text { class }\end{array}$ \\
\hline $\begin{array}{l}\text { MB26 } \\
\left(p h e-12 \text { leu-8spo } o^{+}\right)\end{array}$ & $\mathrm{Phe}^{+}$ & $\begin{array}{l}\mathrm{Leu}^{+} \mathrm{Spo}^{+} \\
\mathrm{Leu}^{+} \mathrm{Spo}^{-} \\
\mathrm{Leu}^{-} \mathrm{Spo}^{+} \\
\text {Leu- }^{-} \mathrm{Spo}^{-}\end{array}$ & $\begin{array}{c}39 \\
20 \\
38 \\
3^{*}\end{array}$ \\
\hline $\begin{array}{l}\text { BD40 } \\
\left(\text { phe-12 argA3 spo }{ }^{+}\right)\end{array}$ & $\mathrm{Arg}^{+}$ & $\begin{array}{l}\mathrm{Phe}^{+} \mathrm{Spo}^{+} \\
\mathrm{Phe}^{+} \mathrm{Spo}^{-} \\
\mathrm{Phe}^{-} \mathrm{Spo}^{+} \\
\mathrm{Phe}^{-} \mathrm{Spo}^{-}\end{array}$ & $\begin{array}{l}5 \dagger \\
18 \\
52 \\
25\end{array}$ \\
\hline
\end{tabular}

- Rare class (four crossovers) suggesting gene order is phe-leu-spo.

† Rare class suggesting gene order is phe-spo-arg.

Table 3. Determination of recombination index (R.I.) between spo-513 and ger-36

\begin{abstract}
A transformation cross was carried out with strain $513\left(\operatorname{Trp}^{-}\right)$as recipient and with a saturating

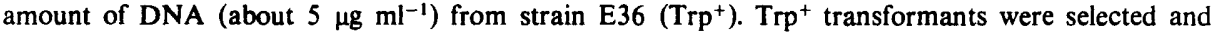
scored for wild-type (recombinant) resistance and germination properties (see Methods). The values were compared with those obtained using a mutant (strain 87.2 ) with a genetically distant mutation.
\end{abstract}

$\begin{array}{lccc} & \overbrace{\text { E36 (ger-36) }} & 87.2(\text { spoOJ) } & \text { R.I. } \\ \text { Expt 1 }\left(\mathrm{Spo}^{+} / \mathrm{Trp}^{+}\right) & 12 / 432(0.027) & 8 / 306(0.026) & 1.03 \\ \left.\text { Expt 2 (Spo }{ }^{+} / \mathrm{Trp}^{+}\right) & 11 / 247(0.044) & 10 / 248(0.040) & 1.10\end{array}$

recombination index (see Lacks \& Hotchkiss, 1960) between the two mutations was determined as described by Coote $(1972 b)$. Cells of strain $513 \operatorname{trpC2}$ were transformed to prototrophy with DNA prepared from strain E36 leuA ger-36, and with DNA from strain 87.2 leuA spoOJ. The ratio of $\mathrm{Spo}^{+}$to $\mathrm{Trp}^{+}$transformants was scored for both crosses (Table 3): ger-36 and leuA are only about $15 \%$ cotransformed (A. Moir, personal communication) so this does not significantly affect the congression of $s p o^{+}$. The recombination index between ger-36 and spo-513 was calculated to be about $1 \cdot 0$, showing that the mutations are not linked and, therefore, that they lie in separate loci.

\title{
DISCUSSION
}

A number of germination mutants of $B$. cereus have been isolated and characterized (Aronson \& Fitz-James, 1975; Stelma et al., 1978, 1980). Some of these form lysozyme-sensitive spores and the defects seem to be related to an alteration in the spore coat. A large number of $B$. subtilis germination mutants have also been obtained (Trowsdale \& Smith, 1975; Moir et al., 1979), but in only one of these has a defect in the spore coat been demonstrated (Moir et al., 1979).

The mutant described in this paper lacks a single spore coat protein which normally forms part of the outermost layer of the spore (Jenkinson et al., 1981). The spores are germination-defective and lysozyme-sensitive and these phenotypes seem to fit in with the idea that the coat structure may determine both germination and resistance properties.

The properties of this mutant support a previous suggestion that lysozyme resistance is conferred primarily by the outer coat layers and requires the synthesis and deposition of the 36K polypeptide (Jenkinson et al., 1981). Lysozyme-sensitive spores are also formed when 


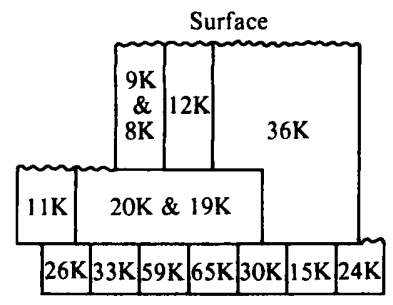

(a) Strain 168

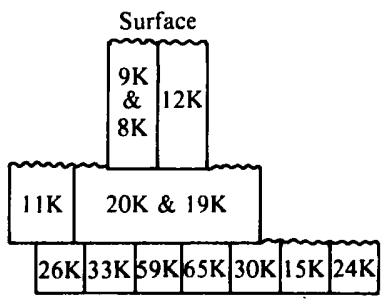

(b) Strain 513

Fig. 6. Schematic diagram of the surface layers of spores of strain $168(a)$ and strain $513(b)$ at $t_{9}$. The diagram is based on the data in Fig. 5 and is subject to the limitations described previously (Jenkinson $e t$ al., 1981); it is not meant to indicate that the proteins are in contiguous blocks or arranged in any lateral order. Each protein is represented as a unit, the area of which approximates to the amount of that protein in the coat extract. Surface exposure is indicated by the serrated edge.

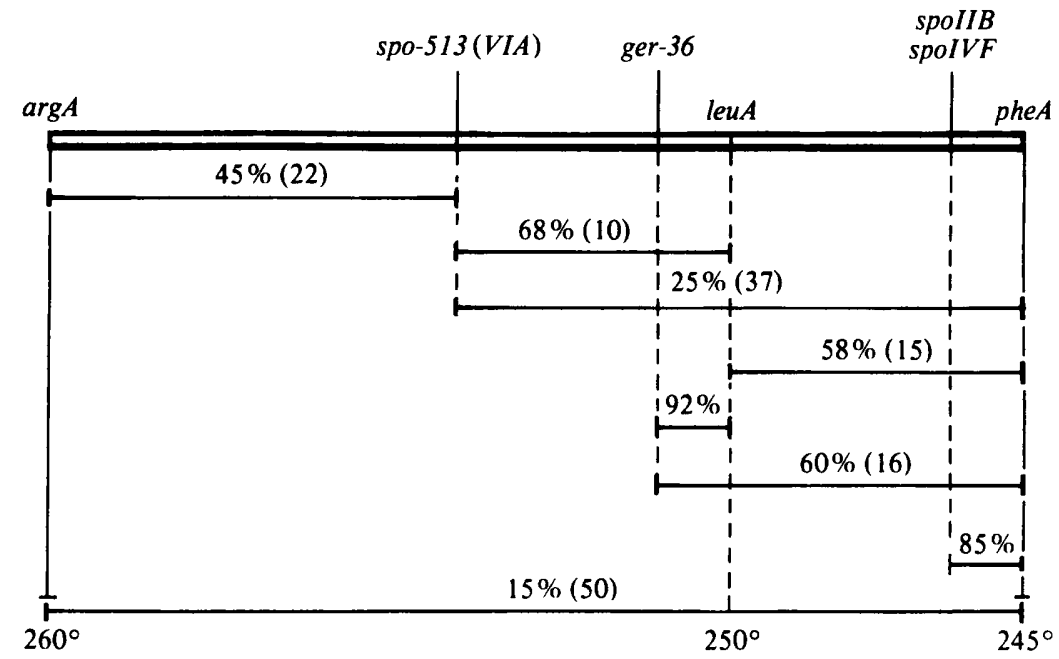

Fig. 7. Map of the pheA-leuA-argA region of the B. subtilis chromosome showing the location of sporulation and germination mutations. Percentages are cotransduction frequencies; figures in parentheses are approximate corrected genetic distances between markers $(100 \times t$, where $t$ is the fractional length of transducing fragment; see Henner \& Hoch, 1980). The location of spoIVF is from Hranueli et al. (1974) and spoIIB and spoIVF are apparently inseparable by phage PBS1 transduction (I. Lamont, unpublished results).

the other major component of the outer layer, a $12 \mathrm{~K}$ polypeptide, fails to be deposited as a result of including PMSF in the sporulation medium (Jenkinson et al., 1981). Since the 12K polypeptide is laid down apparently normally in the absence of the $36 \mathrm{~K}$ polypeptide in this mutant, it appears that these proteins can be deposited independently. This conclusion is supported by the earlier finding that the $12 \mathrm{~K}$ protein can be laid down in the presence of chloramphenicol, and in the absence of synthesis of the $36 \mathrm{~K}$ polypeptide (Jenkinson et al., 1981). The results in this paper and those previously described also show that the $36 \mathrm{~K}$ polypeptide is not necessary for any of the resistance properties of the spores, except lysozyme resistance.

A schematic diagram of the spore outer layers of this mutant at $t_{9}$ is shown in Fig. 6, with a similar representation for the wild-type. This latter diagram has been adapted from that originally devised for wild-type spores (Jenkinson et al., 1981) in which it was not possible to 
state that any one polypeptide specifically covered any other. The results in this paper, however, suggest that the $30 \mathrm{~K}, 24 \mathrm{~K}, 20 \mathrm{~K}, 19 \mathrm{~K}$ and $15 \mathrm{~K}$ polypeptides are covered specifically by the $36 \mathrm{~K}$ polypeptide in the wild-type, since all are more exposed in the mutant. It is expected that the diagrammatic representation may have to be further modified in the light of more data.

The mutation in strain 513 seems separate from other sporulation and germination loci in the pheA-argA region (Fig. 7) and causes a specific defect late in sporulation. Hence, in keeping with the classification of Piggot \& Coote (1976), spo-513 can be provisionally assigned to a new locus spoVIA. Although the exact nature of the mutation in strain 513 is not clear, e.g. whether it is in the structural gene for the $36 \mathrm{~K}$ polypeptide or in a preceding operon, further study of late-blocked mutants should enable the genetic loci controlling the synthesis of this and other coat polypeptides to be more clearly defined.

I am grateful to Professor J. Mandelstam for his continuous guidance and to Angela Maunder for technical assistance. I thank Dr Susan Hill for helpful discussions and R. Warburg for information on unpublished results. This work was supported by the Science Research Council.

\section{REFERENCES}

AKRIGG, A. (1978). Purification and properties of a manganese-stimulated deoxyribonuclease produced during sporulation of Bacillus subtilis. Biochemical Journal 172, 69-76.

Aronson, A. I. \& Fitz-James, P. C. (1975). Properties of Bacillus cereus spore coat mutants. Journal of Bacteriology 123, 354-365.

AYAD, S. R. \& BARKeR, G. R. (1969). The integration of donor and recipient deoxyribonucleic acid during transformation of Bacillus subtilis. Biochemical Journal 113, 167-174.

BONNER, W. M. \& LASkey, R. A. (1974). A film detection method for tritium-labelled proteins and nucleic acids in polyacrylamide gels. European Journal of Biochemistry 46, 83-88.

COOTE, J. G. (1972a). Sporulation in Bacillus subtilis. Characterization of oligosporogenous mutants and comparison of their phenotypes with those of asporogenous mutants. Journal of General Microbiology 71, 1-15.

Coote, J. G. (1972b). Sporulation in Bacillus subtilis. Genetic analysis of oligosporogenous mutants. Journal of General Microbiology 71, 17-27.

Dancer, B. N. \& MAndelstam, J. (1975). Production and possible function of serine protease during sporulation of Bacillus subtilis. Journal of Bacteriology 121, 406-410.

Dion, P. \& Mandelstam, J. (1980). Germination properties as marker events characterizing later stages of Bacillus subtilis spore formation. Journal of Bacteriology 141, 786-792.

GlenN, A. R. \& MANDElstam, J. (1971). Sporulation in Bacillus subtilis 168. Comparison of alkaline phosphatase from sporulating and vegetative cells. Biochemical Journal 123, 129-138.

HENNER, D. J. \& HoCH, J. A. (1980). The Bacillus subtilis chromosome. Microbiological Reviews 44, 57-82.

Hranueli, D., Piggot, P. J. \& Mandelstam, J. (1974). Statistical estimate of the total number of operons specific for Bacillus subtilis sporulation. Journal of Bacteriology 119, 684-690.

JANSSEN. F. W.. Lund. A. J. \& ANDERSON, L. E.
(1958). Colorimetric assay for dipicolinic acid in bacterial spores. Science 127, 26-27.

Jenkinson, H. F., KaY, D. \& Mandelstam, J. (1980). Temporal dissociation of late events in Bacillus subtilis sporulation from expression of genes that determine them. Journal of Bacteriology 141, 793-805.

Jenkinson, H. F., Sawyer, W. D. \& Mandelstam, J. (1981). Synthesis and order of assembly of spore coat proteins in Bacillus subtilis. Journal of General Microbiology 123, 1-16.

Karamata, D. \& Gross, J. D. (1970). Isolation and genetic analysis of temperature-sensitive mutants of $B$. subtilis defective in DNA synthesis. Molecular and General Genetics 108, 277-287.

LACKs, S. \& Hotchkiss, R. D. (1960). A study of the genetic material determining an enzyme activity in Pneumococcus. Biochimica et biophysica acta 39, 508-518.

LAEMMLI, U. K. \& FAVRE, M. (1973). Maturation of the head of bacteriophage T4. I. DNA packaging events. Journal of Molecular Biology 80, 575599.

LAFFERTY, E. \& MoIR, A. (1977). Further studies on conditional germination mutants of Bacillus subtilis 168. In Spore Research 1976, pp. 87-105. Edited by A. N. Barker, J. Wolf, D. J. Ellar, G. J. Dring \& G. W. Gould. London: Academic Press.

LASKEY, R. A. \& Mills, A. D. (1975). Quantitative film detection of ${ }^{3} \mathrm{H}$ and ${ }^{14} \mathrm{C}$ in polyacrylamide gels by fluorography. European Journal of Biochemistry 56, 335-341.

MARMUR, J. (1961). A procedure for the isolation of deoxyribonucleic acid from micro-organisms. Journal of Molecular Biology 3, 208-218.

MoIR, A., Lafferty, E. \& SMrth, D. A. (1979). Genetic analysis of spore germination mutants of Bacillus subtilis 168: the correlation of phenotype with map location. Journal of General Microbiology 111, 165-180.

Pandey, N. K. \& Aronson, A. I. (1979). Properties of the Bacillus subtilis spore coat. Journal of Bacterio$\log y 137,1208-1218$. 
Piggot, P. J. (1973). Mapping of asporogenous mutations of Bacillus subtilis: a minimum estimate of the number of sporulation operons. Journal of Bacteriology 114, 1241-1253.

Piggot, P. J. \& Coote, J. G. (1976). Genetic aspects of bacterial endospore formation. Bacteriological Reviews 40, 908-962.

SADOFF, H. L. (1966). Glucose dehydrogenase soluble. I. Bacillus cereus. Methods in Enzymology 9, 103-107.

Stelma, G. N., Jr, Aronson, A. I. \& Fitz-James, P. (1978). Properties of Bacillus cereus temperaturesensitive mutants altered in spore coat formation. Journal of Bacteriology 134, 1157-1170.

Stelma, G. N. Jr, Aronson, A. I. \& Fitz-James, P.
C. (1980). A Bacillus cereus mutant defective in spore coat deposition. Journal of General Microbiology 116, 173-185.

Sterlini, J. M. \& Mandelstam, J. (1969). Commitment to sporulation in Bacillus subtilis and its relationship to development of actinomycin resistance. Biochemical Journal 113, 29-37.

TAKAHASHI, I. (1963). Transducing phages for Bacillus subtilis. Journal of General Microbiology 31, 211217.

Trowsdale, J. \& SMith, D. A. (1975). Isolation, characterization, and mapping of Bacillus subtilis 168 germination mutants. Journal of Bacteriology $123,83-95$. 